\author{
dr Magdalena TUSIŃSKA \\ Wydział Ekonomii, Uniwersytet Ekonomiczny w Katowicach \\ e-mail: magdalena.tusinska@ue.katowice.pl
}

DOI: 10.15290/ose.2017.06.90.10

\title{
NIERÓWNOŚCI DOCHODOWE I UBÓSTWO W POLSCE NA TLE ZMIAN SYSTEMOWYCH
}

\begin{abstract}
Streszczenie
Celem artykułu jest przedstawienie tendencji zmian poziomu nierówności dochodowych i ubóstwa w Polsce w kontekście zmian systemowych, zachodzących w kraju po drugiej wojnie światowej do czasów obecnych. Postawiono hipotezę, że sam poziom nierówności nie jest wystarczający do oceny tego zjawiska, gdyż istotną rolę odgrywa jego percepcja przez społeczeństwo determinowana czynnikami specyficznymi dla danego kraju. W treści artykułu omówiono kontrowersje związane z kryterium „sprawiedliwego podziału dochodu” oraz zaprezentowano dane statystyczne dotyczące nierówności i ubóstwa, a następnie zestawiono je z opinią społeczeństwa na temat tych zjawisk. Pozwoliło to na wyciagnięcie wniosków, że Polska jest krajem o przeciętnych nierównościach, a na ich ocenę nie bez wpływu pozostaje ciagłość instytucji nieformalnych.
\end{abstract}

Słowa kluczowe: system gospodarczy, nierówności dochodowe, ubóstwo, transformacja gospodarcza, europejski model społeczny

\section{INCOME INEQUALITIES AND POVERTY IN POLAND IN CONTEXT OF ECONOMIC TRANSITION}

\begin{abstract}
Summary
The aim of this paper is to present the level of income inequalities and poverty in Poland. These phenomena are discussed in the context of changes in the economic system which have taken place since the end of the Second World War. The author puts forward a hypothesis that not only the level of disparity itself is crucial but also its perception by society, which is determined by country-specific factors. The paper discusses the controversies associated with the criterion of 'fair income distribution' and presents data concerning inequalities and poverty. It can be concluded that income disparities and poverty in Poland are average and that their assessment is sometimes affected by the normative approach to the issue and continuity of informal institutions.
\end{abstract}

Key words: economic system, income inequalities, poverty, economic transition, European social model

JEL Classification: E02, I32,P00, P10, P20 


\section{Wstęp}

Ekonomia bywa definiowana jako nauka o wzroście i podziale dochodu narodowego, co czyni wskazane obszary tematyczne kluczowym przedmiotem badań przedstawicieli tej nauki. Problematyka dysproporcji w podziale dochodów i bogactwa w społeczeństwie jest także przedmiotem dyskusji reprezentantów wielu dziedzin, którą w ostatnich latach ożywiła wiadomość z początku 2015 roku, że do 2016 roku 1\% najzamożniejszych będzie posiadaczami połowy światowego bogactwa [http://biznes.newsweek.pl] czy przyznanie nagrody Nobla w 2015 roku A. Deatonowi za analizę konsumpcji, ubóstwa i dobrobytu. Do pogłębionej refleksji na temat społeczeństwa, gospodarki i nierówności przyczynił się T. Piketty [2015], jak również R. Wilkinson i K. Pickett [2009].

Kwestie nierówności społecznych, zwłaszcza w ujęciu makroekonomicznym, są jednocześnie przedmiotem dyskusji w Polsce. Aktualność tematu sprawiła, że celem artykułu uczyniono przedstawienie tendencji zmian poziomu nierówności dochodowych i ubóstwa na poziomie krajowym w kontekście zmian systemowych. Nawiązanie do problematyki transformacji systemowej nie jest podyktowane chęcią udokumentowania procesów zachodzących w Polsce po drugiej wojnie światowej, lecz ma za zadanie wskazać możliwe przyczyny postrzegania zjawiska nierówności przez polskie społeczeństwo.

Przyjęto hipotezę, że obiektywny poziom nierówności (wyznaczony współczynnikiem Giniego) nie jest wystarczający do oceny zjawiska, gdyż na ten ma wpływ jego percepcja przez społeczeństwo. Ta z kolei jest kształtowana latami przez uwarunkowania specyficzne dla kraju. Każdy z procesów, który w okresie powojennym dotyczył polskiej gospodarki - transformacja, globalizacja czy integracja - wiąże się ze zmianami systemowymi i jednocześnie oddziałuje na proces podziału dochodów w społeczeństwie. Odwrotna relacja również jest prawdziwa - rzeczywistość gospodarcza i sytuacja społeczna determinują niektóre rozwiązania systemowe. Żadna z tych zmian nie następuje jednak szybko ani automatycznie.

W artykule analizę przede wszystkim prowadzono na poziomie makro, przy czym pojawily się odniesienia do systemów na innych poziomach sprzężonych z gospodarką narodową [Wilkin, 1995, s. 109], w tym szczególnie do megasystemów (gospodarka socjalistyczna, gospodarka rynkowa). Ponadto, przyjęto wąskie rozumienie pojęcia systemu gospodarczego, tj. utożsamiono je z określeniami, takimi jak porządek gospodarczy czy sfera regulacji [Balcerowicz, 1993, s. 14]. W związku z zamiennie stosowanymi w literaturze pojęciami systemu gospodarczego i modelu gospodarczego warto zarazem nadmienić, że niniejszym rozróżnia się je, a treść odwołuje się zarówno do kwestii dotyczących danego systemu gospodarczego (polskiej gospodarki), jak i ujęcia modelowego (np. społecznej gospodarki rynkowej, europejskiego modelu społecznego) obejmującego jedynie najważniejsze wyznaczniki systemu [Swadźba, 2007, s. 26 i n.].

Artykuł składa się ze wstępu, z trzech części i podsumowania. W pierwszej części dokonano wprowadzenia do problematyki sprawiedliwego podziału dochodu jako jednego z kryteriów oceny sprawności systemu gospodarczego. W drugiej części przedstawiono - pod względem wynikowym - dane dotyczące nierówności i ubóstwa w Polsce wraz z komentarzem, by w kolejnej części przejść do prezentacji opinii polskiego społeczeństwa na temat istniejących dysproporcji. W podsumowaniu zawarto najważniejsze wnioski. 
W opracowaniu oparto się na studiach literaturowych oraz analizie dokumentów, raportów i danych statystycznych.

\section{Sprawiedliwy podział dochodu jako kontrowersyjne kryterium oceny sprawności systemu gospodarczego}

Oceniając poziom sprawności rozwiązań systemowych funkcjonujących w różnych krajach, badacze uwzględniają szereg kryteriów, np.: stopę życiową, wzrost gospodarczy, stabilność ekonomiczną, stopień zaspokojenia potrzeb społecznych i niematerialnych czy - kluczowy z racji podjętego tematu - sprawiedliwy podział dochodu [Kozłowski, 1998, s. 21]. Spośród wymienionych, z uwagi na pierwiastek normatywny, to właśnie ostatnie kryterium jest najtrudniejsze do zdefiniowania, gdyż można wskazać wachlarz zasad sprawiedliwości, które mogą służyć ocenie wyniku podziału dochodu, a mianowicie:

- „każdemu wedle zasłużonej nagrody” (w tym marksowska zasada: każdemu według zasług w pracy);

- merytokratyczna - każdemu należy się nagroda proporcjonalnie do wkładu wynikającego z wysiłku (np. pracy) albo według stanowiska;

- uprawnień - zalegitymizowane np.: tradycja, formalnymi decyzjami;

- $\quad$ równości rezultatów - każdemu po równo, wypłaty niezależne od wkładu (praktyka realnego socjalizmu);

- równości szans - „równy start”;

- zaspokajania potrzeb podstawowych - bliska socjaldemokratom (fundament norm prawnych w państwach o rozbudowanej opiekuńczości);

- funkcjonalnej nierówności - wynika z przekonania, że nierówności nagród są następstwem nierównego wkładu jednostek w powodzenie systemu jako funkcjonalnej całości i sa postrzegane jako przyczyniające się do wzrostu efektywności [Morawski, 2011, s. 298-301].

Abstrahując od etycznych aspektów, rozbieżności między zasadami dowodza, iż rozumienie sprawiedliwości jest determinowane m.in. przez system gospodarczy funkcjonujący w danym kraju. Tym samym przejście od gospodarki centralnie planowanej do systemu, w którym zasadniczym regulatorem procesów gospodarczych jest rynek, wiąże się z odejściem od respektowania zasady równości rezultatów. Gospodarka rynkowa, promując przedsiębiorcze jednostki, prowadzi bowiem do wzrostu efektywności i pośrednio do nierównomiernego podziału dochodów. Uznanie zaistniałych dysproporcji za nadmierne uruchamia działania korygujące za pomoca polityki redystrybucyjnej. Rodzaje instrumentów i zakres ich stosowania w poszczególnych krajach gospodarki rynkowej są zróżnicowane - w krajach najbardziej liberalnych postuluje się przede wszystkim zasadę równości szans, natomiast w państwach o bardziej rozbudowanej opiekuńczości fundamentem norm prawnych jest zasada zaspokajania podstawowych potrzeb.

Uniwersalne kryterium porównania i oceny sprawności systemu gospodarczego w zakresie oceny sprawiedliwego podziału dochodu nie istnieje. Nawet w ramach jednego 
megasystemu kraje cechuje zróżnicowanie ograniczeń regulacyjnych, będących zwyczajowo (instytucje nieformalne) lub prawnie ustalonymi (instytucje formalne) normami postępowania. Preferowany poziom opiekuńczości i społeczna akceptacja dysproporcji w podziale dochodów nie kształtuje się w izolacji od: historii, tradycji, religii czy kultury, lecz wykształca się w wyniku procesu historycznego. Jak podkreśliła A. Swidler, socjolog kultury: Kultura nie jest żadnym jednolitym systemem, który popycha driatanie w jakimś

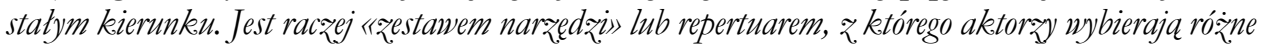
elementy do konstruowania linii swego driatania [cyt. za: Marody, 2015, s. 52]. Większych rozbieżności pod względem stosowanych instrumentów polityki społecznej i gospodarczej należy oczekiwać wśród krajów, które nie sąsiadują ze sobą i/lub których doświadczenia historyczne są bardziej zróżnicowane.

Na podstawie badań różnych systemów gospodarczych i uwzględniając podobieństwo niektórych ich cech buduje się konstrukcje teoretyczne grupujące owe systemy, a przynależności do jednej grupy nie musi dyskwalifikować zróżnicowany stopień dopasowania poszczególnych krajów do modelu. Na przykład, różnic istniejących pomiędzy państwami Unii Europejskiej (UE) nie uznaje się za wystarczające, by przesłonić elementy wspólne, pozwalające mówić o europejskim modelu społecznym (odmiennym od rozwiązań przyjętych np. w Stanach Zjednoczonych), bowiem zasady sprawiedliwości szczególnie szanowane w Europie znacząco odbiegają od tych, które wyznaje bardziej liberalne społeczeństwo amerykańskie.

\section{Systemy i modele kształtujące system gospodarczy w Polsce}

Po drugiej wojnie światowej Polska należała do grupy krajów socjalistycznych, dla której był charakterystyczny system gospodarki centralnie planowanej, stosunkowo „równo dzielącej płace”. Po ponad czterdziestu latach rozpoczęła się transformacja prowadząca do systemu gospodarki rynkowej, a otwierająca się gospodarka stała się uczestnikiem procesu globalizacji i krajem dążącym do integracji z Europą Zachodnią. W latach dziewięćdziesiątych XX wieku w gospodarce światowej nastapiło przyspieszenie procesu globalizacji związanej z wpływem modelu liberalizmu amerykańskiego i intensyfikacją konkurencji, które przyczyniły do coraz większej polaryzacji dochodów nie tylko w skali globalnej, ale i w ramach krajów. Otwierająca się polska gospodarka stała się uczestnikiem procesu globalizacji i rozpoczęła starania o akcesję do UE. Przeobrażenia systemowe w Polsce zaczęły być poddawane sile oddziaływania modelu europejskiego.

Choć niektórzy badacze pisali o konwergencji systemowej w ramach UE [Swadźba, 2007], a nawet o: (...) ujednoliceniu systemu spoteczno-ekonomicznego, struktury gospodarczej killku państw na drodze unifikacii środków polityki ekonomicznej $i$ spotecznej w celu stworzenia miedsynarodowego komplekesu gospodarczego [Lis, Miklaszewski, 1993, s. 11], to akurat system redystrybucji nie stał się przedmiotem integracji, co jednak nie przeszkadzało od lat funkcjonować wspomnianemu pojęciu europejskiego modelu społecznego. U jego podstaw leży idea wspierania potrzebujących pomocy (z powodu: utraty pracy, niepełnosprawności, choroby, emerytury, biedy itd.). Istniejące w Europie rozwiązania nawiązują do tradycji dwóch nurtów w zakresie tworzenia bezpieczeństwa socjalnego - systemu opartego 
na ubezpieczeniach społecznych wywodzących się od reform Ottona von Bismarcka i systemu zabezpieczenia powszechnego zaproponowanego przez Williama Beveridge'a. Pierwsze instytucje konstruujące państwo dobrobytu tworzono już pod koniec XIX wieku i odegrały one znaczącą rolę w modernizacji państw europejskich, łagodzeniu napięć społecznych będących konsekwencją wahań koniunktury, zmieniających się trendów demograficznych czy przemian strukturalnych [Mitręga, 1999, s. 51-53]. Przywiązanie do idei bezpieczeństwa socjalnego sprawiło, że wymiar społeczny UE został ujęty w Traktacie Rzymskim, lecz przełomowy w tym zakresie był Jednolity Akt Europejski (z 1986 roku), wraz z którym kwestie społeczne nabrały trwałego zobowiązania. Postulowano prowadzenie takiej polityki przez Wspólnotę, która przyczyniłaby się do wzmocnienia jej społecznej spójności. Wraz z pogłębianiem procesu integracji, aspekty te były uwzględniane w różnych dokumentach kluczowych dla współpracy w ramach UE [Pęciak, Tusińska, 2015, s. 117-118], obejmujących zarazem kraje, które przystępowały do Unii w późniejszych latach.

Zgodnie z przyjętą w 1997 roku Konstytucja, w Polsce są wdrażane założenia modelu społecznej gospodarki rynkowej (SGR). Próbując wzorować się na niemieckich rozwiązaniach przyjęto założenie o gospodarce opartej na: wolności działalności gospodarczej, własności prywatnej, ale również solidarności, dialogu i współpracy partnerów społecznych [Konstytucja RP..., 1997, art. 20]. Polskę zalicza się do jednej „,modelowej” grupy krajów z: Niemcami, Francją, Austrią i krajami Beneluksu, w ramach której obserwuje się wpływ modelu Bismarcka - świadczenia zabezpieczenia społecznego bazują na ubezpieczeniach powiązanych z zatrudnieniem, zaś znaczny obowiązek zapewnienia odpowiedniego dochodu i opieki zdrowotnej spoczywa na rodzinie. Dopiero ewentualne luki w sferze ochrony socjalnej powinien wypełniać system pomocy społecznej [Mitręga, 1999, s. 54].

W ostatnich latach kwestie społeczne zyskały na znaczeniu w Europie także w wyniku kryzysu 2008+. Choć obecne podejście bywa krytykowane przez zwolenników modelu anglosaskiego [Bieńkowski, 2010, s. 166-172] od 2010 roku jest realizowana strategia „Europa 2020”, która postuluje wzrost sprzyjający włączeniu społecznemu - co ważne - na równi ze wzrostem inteligentnym i zrównoważonym. Mimo że postanowienia strategii nie mają wiążącego charakteru (w tym sensie, że UE nie dysponuje instrumentami przymusu w tym zakresie), kraje sa mobilizowane do podejmowania reform dzięki tzw. peer pressure wynikającej z otwartej metody koordynacji [Trubek, 2005, s. 343]. Warto nadmienić, iz itotny wpływ na cele strategii miały kraje skandynawskie oraz ich model systemu gospodarczego.

\section{Nierówności i ubóstwo w Polsce}

Najpopularniejszą miarą rozkładu dochodów jest współczynnik Giniego. Przybiera on wartości od 0 (rozkład jednorodny) do 100 (gdyby wszystkie osoby - poza jedna miały dochód zerowy), co oznacza, że im wyższa jest wartość wskaźnika, tym większy jest stopień koncentracji dochodów i większe ich zróżnicowanie [Malinowski, 2016, s. 21-25]. 
W tabeli 1. przedstawiono wartości tego współczynnika w Polsce od lat sześćdziesiątych ubiegłego wieku do czasów obecnych.

TABELA 1.

Nierówności dochodowe w Polsce

\begin{tabular}{|l|c|c|c|c|c|c|c|c|}
\hline Okres & $\begin{array}{c}\text { Lata } \\
\text { sześć- } \\
\text { dzie- } \\
\text { siąte }\end{array}$ & $\begin{array}{c}\text { Lata } \\
\text { siedem- } \\
\text { dzie- } \\
\text { siąte }\end{array}$ & $\begin{array}{c}\text { I po- } \\
\text { towa lat } \\
\text { osiem- } \\
\text { dziesią- } \\
\text { tych }\end{array}$ & $\begin{array}{c}\text { II po- } \\
\text { łowa lat } \\
\text { osiem- } \\
\text { dziesią- } \\
\text { tych }\end{array}$ & $\begin{array}{c}\text { I po- } \\
\text { łowa } \\
\text { lat } \\
\text { dzie- } \\
\text { więć- } \\
\text { dzie- } \\
\text { siątych }\end{array}$ & $\begin{array}{c}\text { II po- } \\
\text { łowa } \\
\text { lat } \\
\text { dzie- } \\
\text { więć- } \\
\text { dzie- } \\
\text { siątych }\end{array}$ & $\begin{array}{c}\text { 2000- } \\
\mathbf{2 0 0 5}\end{array}$ & $\begin{array}{c}\mathbf{2 0 0 6 -} \\
\mathbf{2 0 1 4}\end{array}$ \\
\hline $\begin{array}{l}\text { Współczynnik } \\
\text { Giniego }\end{array}$ & 26,68 & 23,78 & 23 & 24 & 28,32 & 32,3 & 34,17 & 31,55 \\
\hline
\end{tabular}

Źródło: [https://www.wider.unu.edu/download/WIID3.3].

Rozkład dochodów w okresie powojennym w Polsce wydaje się w znacznej mierze odzwierciedlać specyfikę systemu gospodarczego - pierwsza połowa danych (tabela 1.). Dotyczy on okresu funkcjonowania gospodarki sterowanej centralnie, kontrolującej wynagrodzenia i ,równo dzielącej” produkt narodowy. Do lat osiemdziesiątych XX wieku wartość współczynnika średnio wynosiła 25. Wejście na drogę transformacji w kierunku wolnorynkowej gospodarki kapitalistycznej musiało przyczynić się do narastania dysproporcji, co potwierdzają wartości współczynnika Giniego rosnące od lat dziewięćdziesiątych, jednak dyskusyjne byłoby kategoryczne uznanie go za zbyt wysoki. Największe rozwarstwienie dochodów miało miejsce w latach 2000-2005 (średnio 34,17, tabela 1.), co mogło wywoływać pewien dysonans wynikający z rozbieżności między rzeczywistością a oczekiwaniami części społeczeństwa wobec realizacji koncepcji SGR.

W tabeli 2. zaprezentowano dane dotyczące nierówności mierzonych współczynnikiem Giniego w okresie po przystąpieniu do UE. Uzupełniono je o statystyki obejmujące ubóstwo i wykluczenie, które często są konsekwencją skrajnych nierówności.

Dane (tabela 2.) świadczą o pozytywnym trendzie - zmniejszaniu się nierówności dochodowych i ubóstwa. W ciagu dekady niemal wszystkie wskaźniki obniżyły się niektóre o połowę i więcej (wskaźniki deprywacji materialnej). Jedyny wskaźnik, którego wartość była wyższa w 2014 roku niż w 2005, to gniazdownictwo osób w wieku 25-34. Jednak nie musiało to być związane wyłącznie z aspektem materialnym, ale mogło być efektem zmian na rynku bankowym i nieruchomości czy uwarunkowań społeczno-kulturowych. W Polsce nie wystąiła więc tendencja wzrostowa w zakresie dysproporcji dochodowych. Nierówności w ostatnich latach były średnio niższe niż w okresie 2000-2005 (por. tabele: 1. i 2.) oraz jednocześnie malejące i obecnie nie odbiegaja od wartości wyznaczonych dla całej UE. 
TABELA 2.

Nierówności dochodowe, ubóstwo i wykluczenie w Polsce w latach 2005-2014

\begin{tabular}{|c|c|c|c|c|c|c|c|c|c|c|}
\hline \multicolumn{1}{|c|}{ Wskaźnik } & $\mathbf{2 0 0 5}$ & $\mathbf{2 0 0 6}$ & $\mathbf{2 0 0 7}$ & $\mathbf{2 0 0 8}$ & $\mathbf{2 0 0 9}$ & $\mathbf{2 0 1 0}$ & $\mathbf{2 0 1 1}$ & $\mathbf{2 0 1 2}$ & $\mathbf{2 0 1 3}$ & $\mathbf{2 0 1 4}$ \\
\hline $\begin{array}{l}\text { Współczynnik } \\
\text { Giniego }\end{array}$ & 35,6 & 33,3 & 32,2 & 32 & 31,4 & 31,1 & 31,1 & 30,9 & 30,7 & 30,8 \\
\hline $\begin{array}{l}\text { Wskaźnik zagro- } \\
\text { żenia ubóstwem } \\
\text { lub wykluczeniem } \\
\text { społecznym (w \%) }\end{array}$ & 45,3 & 39,5 & 34,4 & 30,5 & 27,8 & 27,8 & 27,2 & 26,7 & 25,8 & 24,7 \\
\hline $\begin{array}{l}\text { Wskaźnik bardzo } \\
\text { niskiej intensyw- } \\
\text { ności pracy wos- } \\
\text { podarstwie domo- } \\
\text { wym (w \%) }\end{array}$ & 14,3 & 12,4 & 10,1 & 8 & 6,9 & 7,3 & 6,9 & 6,9 & 7,2 & 7,3 \\
\hline $\begin{array}{l}\text { Wskánik depry- } \\
\text { wacji materialnej } \\
\text { (w \%) }\end{array}$ & 50,8 & 44 & 38,2 & 32,3 & 29,5 & 28,4 & 26,4 & 27,8 & 25,5 & 22,2 \\
\hline $\begin{array}{l}\text { Wskaźnik pogłe- } \\
\text { bionej deprywacji } \\
\text { materialnej (w \%) }\end{array}$ & 33,8 & 27,6 & 22,3 & 17,7 & 15 & 14,2 & 13 & 13,5 & 11,9 & 10,4 \\
\hline $\begin{array}{l}\text { Wskaźnik zagro- } \\
\text { żenia ubóstwem } \\
\text { bez uwzględnie- } \\
\text { nia w dochodach } \\
\text { transferów spo- } \\
\text { tecznych (w \%) }\end{array}$ & 50,8 & 49,1 & 47,1 & 44,1 & 42,6 & 43,3 & 43,4 & 42,7 & 43 & 43,7 \\
\hline $\begin{array}{l}\text { Wskaźnik zagro- } \\
\text { żenia ubóstwem } \\
\text { po transferach } \\
\text { społecznych (w \%) }\end{array}$ & 20,5 & 19,1 & 17,3 & 16,9 & 17,1 & 17,6 & 17,7 & 17,1 & 17,3 & 17 \\
\hline $\begin{array}{l}\text { Wskaźnik gniaz- } \\
\text { downictwa osób } \\
\text { w wieku 25-34 } \\
\text { lat (w \%) }\end{array}$ & 36,4 & 37,8 & 38,8 & 39,5 & 40,1 & 40,7 & 44,4 & 43,4 & 43,5 & 44,1 \\
\hline
\end{tabular}

* Definicje wskaźników: [http://strateg.stat.gov.pl/MetaDane/Metryczki].

Źródło: [http://strateg.stat.gov.pl/].

\section{Percepcja nierówności i ubóstwa w Polsce}

Dane zaprezentowane powyżej wskazują na stopniową poprawę sytuacji społecznej. W tabeli 3., celem weryfikacji, jak społeczeństwo ocenia zachodzące zmiany, przedstawiono wyniki badań Eurobarometru, które dodatkowo poruszają kwestie dotyczące rynku pracy, jak również są powiązane z problematyką nierówności. 
TABELA 3.

Wyniki badań Eurobarometru dotyczących kwestii społecznych*

\begin{tabular}{|l|c|c|c|c|c|c|}
\hline \multicolumn{1}{|c|}{ Jak oceniasz ... } & $\mathbf{2 0 0 9}$ & $\mathbf{2 0 1 0}$ & $\mathbf{2 0 1 1}$ & $\mathbf{2 0 1 2}$ & $\mathbf{2 0 1 3}$ & $\mathbf{2 0 1 4}$ \\
\hline $\begin{array}{l}\text {....sytuację w kwestii sposobu } \\
\text { radzenia sobie z nierównościami } \\
\text { i ubóstwem w Twoim kraju? }\end{array}$ & -2.4 & $-2,1$ & -3 & $-3,7$ & $-3,1$ & $-3,1$ \\
\hline $\begin{array}{l}\text {...swoją bieżącą sytuację zawo- } \\
\text { dową? }\end{array}$ & 1 & 1,2 & 0,7 & $-0,3$ & 0,3 & 0,4 \\
\hline $\begin{array}{l}\text {...sytuację finansową w swoim } \\
\text { gospodarstwie domowym? }\end{array}$ & 0,2 & 0,1 & 0,1 & $-0,5$ & 0,2 & 0,1 \\
\hline ...sytuację na rynku pracy? & $-3,2$ & $-3,2$ & $-3,9$ & $-4,9$ & $-4,8$ & $-4,5$ \\
\hline ...zasiłki dla bezrobotnych? & -3.4 & $-3,1$ & $-3,5$ & $-4,8$ & $-4,3$ & $-4,1$ \\
\hline
\end{tabular}

* Skala odpowiedzi respondentów: -10: bardzo źle; -3,33: raczej źle; 3,33: raczej dobrze; 10: bardzo dobrze.

Źródło: [Future of Europe, 2014].

Konfrontacja danych obiektywnych (tabela 2.) z subiektywnymi (tabela 3.) pokazuje, iż percepcja nierówności społecznych nie pokryła się z rzeczywistym stanem. Opinia publiczna w większości przypadków negatywnie oceniła poziom nierówności i ich spadek nie znalazł (wymiernego) odzwierciedlenia w świadomości badanych. Podobnych wniosków dostarcza analiza odpowiedzi na pytania dotyczące rynku pracy. Wśród możliwych i niewykluczających się nawzajem przyczyn nastawienia polskiego społeczeństwa można wskazać:

- „klimat społeczny” (pobudzanie w ostatnich latach wrażliwości na kwestie nierówności i ubóstwa);

- nieznajomość niektórych pojęć i porównywanie własnego dochodu z poziomem życia obywateli krajów Europy Zachodniej, zwłaszcza Niemiec;

- uwarunkowania historyczne - przywiązanie do równego „dzielenia płac”.

W kontekście tematyki niniejszego artykułu warto zastanowić się nad ostatnią z przyczyn, bowiem problematyka nierówności dochodowych zaczęła być dostrzegana zwłaszcza w okresie transformacji systemowej i otwierania się na Europę Zachodnią. Mimo że w UE spójność społeczna zajmuje wysoką pozycję w hierarchii celów, to nie jest ona równoznaczna z niemal powszechnym zrównaniem poziomu życia w czasach Polski Ludowej, co przez niektórych nadal może być uznawane za sprawiedliwe i zaletę ówczesnego systemu.

Wydaje się, że narastanie dysproporcji było odczuwalne i negatywnie odbierane nie tyle ze względu na ich skalę, co raczej specyfikę odbioru procesu zmian przez część społeczeństwa. Nie bez znaczenia mógł pozostawać fakt, że beneficjentami prywatyzacji $\mathrm{i}$ innych zmian w procesie transformacji byli profesjonaliści. W przeciwieństwie do nich, znaczna część klasy robotniczej i chłopskiej znalazła się w sferze niedostatku, a czynnikami degradacji stały się: bezrobocie, transfer z sektora publicznego do peryferyjnych segmentów sektora prywatnego, naruszanie i ograniczanie podstawowych praw socjalnych [Gilejko, 2008, s. 48-56]. W strukturze gospodarki centralnie planowanej dominował 
przemysł ciężki, stąd udział klasy robotniczej, która czuła się niesprawiedliwie potraktowana, był większy niż odsetek osób, które odnalazły się w nowej sytuacji. Ponadto, korzyści często odnosiły jednostki korzystające z renty władzy, przy czym w czasach gospodarki centralnie planowanej kryteria awansu były raczej polityczne niż merytoryczne. W związku z powszechnymi zachowaniami typu rent-seeking, jednostki, które odniosły sukces zawodowy także w sposób zasłużony, mogły być negatywnie postrzegane.

Mimo że dane w tabeli 3. obejmują lata 2009-2014, czyli już po zakończeniu transformacji, nie oznacza to, że zachowania i podejście charakterystyczne dla poprzedniego systemu odeszły w zapomnienie. Zmiany instytucjonalne nie dokonują się wyłącznie w wyniku wzorowania się na przyjętych w innych państwach rozwiązaniach i ich dyfuzji ani nie sa prostą konsekwencją działań „optymalizacyjnych”. Zależą one od specyficznej dla danego terytorium ścieżki przemian (path-dependency), ale i natury instytucji [Federowicz, 2004, s. 137 i n.]. Ciagłość instytucji nieformalnych decyduje o tym, że zmiany systemu mają raczej ewolucyjny aniżeli rewolucyjny charakter. Poza tym, pewne postawy, obserwowane na poziomie poszczególnych jednostek, trudniej przebijają się na poziom makro i stają się utrwalonymi wzorcami zachowań symptomatycznymi dla danego społeczeństwa. Wraz z upływem lat subiektywna ocena społeczeństwa może być zatem bardziej spójna z obiektywnymi danymi.

\section{Podsumowanie}

Po drugiej wojnie światowej Polska przeszła transformację do gospodarki centralnie planowanej, następnie, po ponad czterdziestu latach, transformację do gospodarki rynkowej. W latach dziewięćdziesiątych przyjęto model społecznej gospodarki rynkowej, który zakłada liberalizm w sprawach gospodarczych przy jednocześnie dobrze rozwiniętym zabezpieczeniu społecznym. Od ponad dziesięciu lat Polska jest krajem członkowskim UE i choć istnieja uzasadnione wątpliwości, czy konwergencja obejmuje sferę redystrybucji, to niełatwo byłoby podważyć opinię, że europejski model społeczny wywiera wpływ na rozwiązania systemowe przyjmowane w Polsce - nawet jeśli w zakresie redystrybucji nie mają one wiążącego charakteru.

Polskę należy uznać za kraj o przeciętnych (i malejących) nierównościach oraz redukujący ubóstwo, co jest zgodne z europejską ideą społeczno-ekonomicznej. Jak udowodniono, w opinii społeczeństwa łagodzenie nierówności następuje zbyt powoli i stąd sceptyczny odbiór istniejących dysproporcji. Systemy gospodarcze ulegają ewolucji, przy czym najwolniej zmieniają się ludzkie postawy, będące składową instytucji nieformalnych. Przywiązanie części polskiego społeczeństwa do poprzedniego systemu może wyjaśniać brak akceptacji wobec istniejących nierówności, które - wbrew temu, że obiektywnie uznaje się je za przeciętne - są wyższe niż w czasach gospodarki centralnie planowanej. Co więcej, statystyka bada zjawiska masowe i nie odzwierciedla subiektywnych odczuć pojedynczych osób bądź całych grup obywateli. Osobnym problemem jest to, że poczucie niesprawiedliwości powoduje osłabianie więzi społecznych i brak zaufania, co przekłada się na wyniki gospodarcze. 


\section{Literatura}

Balcerowicz L., 1993, Systemy gospodarcze. Elementy analisy porónnawnczej, Monografie i Opracowania nr 281, Oficyna Wydawnicza Szkoły Głównej Handlowej, Warszawa.

Bieńkowski W., 2010, Unia Europejska a dylematy nowych państw cztonkowskich-praypadek Polski, [w:] Wrrost gospodarçy cry bezpieczeństwo socjalne?, W. Bieńkowski, M.-J. Radło (red.), Wydawnictwo Naukowe PWN, Warszawa.

Future of Europe, European Commission, Special Eurobarometer 413, http://ec.europa.eu/ public_opinion/archives/ebs/ebs_413_en.pdf (data wejścia: 05.11.2016).

Gilejko L.K., 2008, Dylematy drugiej dekady polskiej transformacji, Akademia Humanistyczna im. Aleksandra Gieysztora, Pułtusk.

http://biznes.newsweek.pl/1-procent-superbogaczy-bedzie-mialo-wiecej-niz-resztaswiata,artykuly,355428,1.html (data wejścia: 19.07.2016).

http://strateg.stat.gov.pl/ (data wejścia: 15.07.2016).

https://www.wider.unu.edu/download/WIID3.3 (data wejścia: 15.07.2016).

Konstytucja RP ₹ 1997 roku, http://isap.sejm.gov.pl/ (data wejścia: 15.07.2016).

Kozłowski S., 1998, Systemy ekonomiczne. Analiza porównawcza, Wydawnictwo Uniwersytetu Marii Curie-Skłodowskiej, Lublin.

Lis S. Miklaszewski S., 1993, Kraje europejskie wobec wspótçesnych procesón integracyjnych, PAN, Wydawnictwo „Secesja”, Kraków.

Malinowski G.S., 2016, Nierówności i wærost gospodarçy. Sojusznicy czy wrogonne, Wydawnictwo Naukowe PWN SA, Warszawa.

Marody M., 2015, Swojskość i prayssz̧ość, [w:] Reforma kulturowa 2020 - 2030 - 2040. Sukces nymaga zmian, Krajowa Izba Gospodarcza, Warszawa.

Mitręga D., 1999, Europejski model zabespieczenia spolecznego - rzecsymistość çy uy žwanie dla praysszłości, [w:] Europejska integracja gospodarcza - w kierunku jednolitego systemu gospodarczego,

S. Swadźba (red.), Wydawnictwo Uczelniane Akademii Ekonomicznej, Katowice.

Morawski W., 2011, Socjologia ekonomiczna, Wydawnictwo Naukowe PWN, Warszawa.

Pęciak R., Tusińska M., 2015, The fight against poverty in the European Union - expectations versus reality, "Journal of International Studies", vol. 8, no. 2, DOI: 10.14254/20718330.2015/8-2/10.

Piketty T., 2015, Kapital w XXI wieku, Wydawnictwo Krytyki Politycznej, Warszawa.

Swadźba S., 2007, Integragja i globalizacja a system gospodarazy. Konsekwencje dla Polski, Wydawnictwo Akademii Ekonomicznej, Katowice.

Trubek D., Trubek L.G., 2005, Hard and Soft Law in the Construction of Social Europe: the Role of the Open Method of Co-ordination, "European Law Journal", vol. 11, no. 3.

Wilkin J., 1995, Jaki kapitalizm, jaka Polska?, Wydawnictwo Naukowe PWN, Warszawa.

Wilkinson R., Pickett K., 2009, The Spirit Level. Why Greater Equality Makes Societes Stronger, Bloomsburry Press, New York. 
